\title{
EFFECT OF PREVIOUS STARVATION ON THE RESPONSE OF PLASMA LIPIDS AND FREE FATTY ACIDS TO A FAT MEAL *
}

\author{
BY MARGARET J. ALBRINK † AND ROBERT S. NEUWIRTH $\ddagger$ \\ (From the Department of Internal Medicine, Yale University School of Medicine, \\ New Haven, Conn.)
}

(Submitted for publication July 30, 1959; accepted August 20, 1959)

Plasma free fatty acids (also variously referred to as nonesterified fatty acids and unesterified fatty acids) have assumed importance as a small but very rapidly metabolized component of serum lipids $(1,2)$. Their derivation from the fat of adipose tissue has been demonstrated and may represent an important form in which stored fat is mobilized, transported and made available for fuel during starvation ( 3 ).

The concentration of free fatty acids (FFA) in plasma increases during starvation (4), in the "metabolic" starvation of diabetic acidosis (5) and of hyperthyroidism (6). When an overnight fast is terminated by the administration of 50 to $100 \mathrm{~g}$ of carbohydrate, an abrupt fall in concentration of plasma FFA occurs within one-half hour and lasts for several hours, and a similar but less marked drop follows a protein meal $(1,2)$. On the other hand, following a fat meal of equal or greater caloric value, the FFA either do not change appreciably or rise much as they do during a similar period of fasting $(2,7)$.

The decrease in concentration of FFA appears to occur in response to an increase in carbohydrate utilization. The absence of such a drop in concentration after a fat meal would seem to indicate insensitivity of the FFA regulatory system to fat or merely the substitution of FFA derived from ingested fat for those derived from adipose fat (3). An alternative possibility is herein suggested, namely that relative inefficiency of fat metabolism in persons adapted to a high car-

* Supported (in part) by Grant no. H-3498 C from the National Heart Institute, National Institutes of Health, Bethesda, Md.

$\dagger$ This work was done during tenure of an Established Investigatorship of the American Heart Association.

$¥$ Some of the data in this article represent work done in fulfillment of the thesis requirement for the degree of Doctor of Medicine at Yale University School of Medicine. bohydrate diet might account for the failure of a fat meal to cut off the FFA-mobilizing mechanism. Any nutritional or metabolic maneuvers aimed at increasing fat combustion might alter the response of plasma FFA to a fat meal.

The present study is concerned with the change in plasma lipids including FFA when a fat meal was administered at the end of a period of starvation lasting for several days.

\section{MATERIALS AND METHODS}

The subjects, who were in their twenties and were free of known disease, were 6 males, and 2 females. A third woman became ill from the effects of the first 24 hours of starvation and had to be dropped from the study. To 6 of the subjects a fat breakfast was given after an overnight fast, and again at the end of a period of starvation lasting from 2 to 7 days. During the starvation nothing but water was ingested. The subjects carried on their usual activities despite the discomforts of starvation.

The breakfast given to 5 of the 6 subjects receiving the fat meal consisted of 2 eggs, $28 \mathrm{~g}$ butter, and $60 \mathrm{ml}$ heavy cream scrambled together. This meal supplies $60 \mathrm{~g}$ of fat, $12 \mathrm{~g}$ protein, and no carbohydrate. The sixth subject (B. B.) was given the same meal with the difference that the egg white was removed, thus eliminating the small amount of protein present in the breakfast.

In order to compare the effects of the fat breakfast with the effects of a carbohydrate meal, two additional male subjects were fed, after an overnight fast, $100 \mathrm{~g}$ of glucose dissolved in $400 \mathrm{ml}$ of water flavored with lemon juice. The same amount of gluçose was again administered after 3 days of starvation.

At intervals before and after the test meals and in some instances during the starvation, blood was drawn from an antecubital vein in a heparinized syringe, immediately centrifuged at room temperature, and the plasma separated from the cells. An aliquot for FFA determination was precipitated in the extraction mixture within onehalf hour of the venipuncture.

FFA were determined by the Method of Dole (2), using a modified method of standardizing the alkali (8). Total fatty acids (9), total cholesterol (10) and lipid 
TABLE I

Changes in plasma lipids following a fat meal given after an overnight fast (control) and terminating a period of several days' starvation

\begin{tabular}{|c|c|c|c|c|c|c|}
\hline $\begin{array}{l}\text { Subject } \\
\text { Sex }\end{array}$ & & $\underset{\mathbf{B k}^{*}}{\text { Time after }}$ & Cholesterol & Lip. $P$ & $\begin{array}{l}\text { Triglyceride } \\
\text { fatty acids }\end{array}$ & FFA \\
\hline \multirow[t]{3}{*}{ A. $\mathbf{M}$. } & Control & $\begin{array}{c}h r s \\
\text { Fasting } \\
3 \\
5\end{array}$ & $\begin{array}{c}m g / 100 m l \\
216 \\
202 \\
197\end{array}$ & $\begin{array}{c}m g / 100 m l \\
10.5 \\
10.4 \\
11.0\end{array}$ & $\begin{array}{c}m E q / L \\
2.3 \\
7.9 \\
10.0\end{array}$ & $\begin{array}{c}m E q / L \\
0.38 \\
0.47 \\
0.64\end{array}$ \\
\hline & $\begin{array}{l}\text { Refeeding on } 4 \text { th day } \\
\text { of starvation }\end{array}$ & $\begin{array}{c}\text { Fasting } \\
3 \\
5\end{array}$ & $\begin{array}{l}219 \\
240 \\
213\end{array}$ & $\begin{array}{r}9.9 \\
9.2 \\
11.3\end{array}$ & $\begin{array}{l}5.5 \\
9.7 \\
6.7\end{array}$ & $\begin{array}{l}1.40 \\
0.79 \\
0.63\end{array}$ \\
\hline & Repeat 1 wk later & $\begin{array}{c}\text { Fasting } \\
3 \\
5\end{array}$ & $\begin{array}{l}194 \\
218 \\
211\end{array}$ & $\begin{array}{r}9.5 \\
11.0 \\
10.3\end{array}$ & $\begin{array}{l}3.0 \\
6.0 \\
6.0\end{array}$ & $\begin{array}{l}0.50 \\
0.40 \\
0.55\end{array}$ \\
\hline \multirow[t]{2}{*}{ B. B. } & Control & $\begin{array}{c}\text { Fasting } \\
3 \\
5\end{array}$ & $\begin{array}{l}202 \\
190 \\
193\end{array}$ & $\begin{array}{l}9.2 \\
8.3 \\
9.7\end{array}$ & $\begin{array}{l}3.4 \\
4.4 \\
5.0\end{array}$ & $\begin{array}{l}0.38 \\
0.55 \\
0.75\end{array}$ \\
\hline & $\begin{array}{l}\text { Refeeding on } 4 \text { th day } \\
\text { of starvation }\end{array}$ & $\begin{array}{c}\text { Fasting } \\
3 \\
5\end{array}$ & $\begin{array}{l}250 \\
245 \\
243\end{array}$ & $\begin{array}{l}10.0 \\
10.8 \\
10.7\end{array}$ & $\begin{array}{l}5.8 \\
6.3 \\
6.1\end{array}$ & $\begin{array}{l}2.63 \\
1.74 \\
1.79\end{array}$ \\
\hline \multirow[t]{2}{*}{ R. N. } & Control & $\underset{3}{\text { Fasting }}$ & $\begin{array}{l}238 \\
257\end{array}$ & $\begin{array}{l}7.8 \\
8.3\end{array}$ & $\begin{array}{l}6.7 \\
6.6\end{array}$ & $\begin{array}{l}0.41 \\
0.48\end{array}$ \\
\hline & $\begin{array}{l}\text { Refeeding on } 8 \text { th day } \\
\text { of starvation }\end{array}$ & $\begin{array}{c}\text { Fasting } \\
\mathbf{3}\end{array}$ & $\begin{array}{l}275 \\
254\end{array}$ & $\begin{array}{r}9.5 \\
10.1\end{array}$ & $\begin{array}{l}6.4 \\
8.2\end{array}$ & $\begin{array}{l}2.25 \\
1.71\end{array}$ \\
\hline \multirow[t]{2}{*}{ S. $\underset{\mathrm{M}}{\mathrm{H}}$} & Control & $\begin{array}{c}\text { Fasting } \\
3 \\
5\end{array}$ & $\begin{array}{l}256 \\
253 \\
247\end{array}$ & $\begin{array}{r}9.7 \\
11.3 \\
9.2\end{array}$ & $\begin{array}{l}3.2 \\
5.3 \\
6.0\end{array}$ & $\begin{array}{l}0.25 \\
0.42 \\
0.65\end{array}$ \\
\hline & $\begin{array}{l}\text { Refeeding on 3rd day } \\
\text { of starvation }\end{array}$ & $\begin{array}{c}\text { Fasting } \\
3 \\
5\end{array}$ & $\begin{array}{l}239 \\
244 \\
235\end{array}$ & $\begin{array}{r}9.7 \\
10.2 \\
10.3\end{array}$ & $\begin{array}{l}4.5 \\
4.7 \\
3.1\end{array}$ & $\begin{array}{l}2.01 \\
1.26 \\
1.28\end{array}$ \\
\hline \multirow[t]{2}{*}{$\underset{F}{J} \cdot G}$. & Control & $\begin{array}{c}\text { Fasting } \\
3 \\
5\end{array}$ & $\begin{array}{l}186 \\
193 \\
185\end{array}$ & $\begin{array}{l}8.1 \\
8.5 \\
9.4\end{array}$ & $\begin{array}{l}2.3 \\
4.6 \\
2.9\end{array}$ & $\begin{array}{l}0.50 \\
0.62 \\
0.69\end{array}$ \\
\hline & $\begin{array}{l}\text { Refeeding on } 3 \text { rd day } \\
\text { of starvation }\end{array}$ & $\begin{array}{c}\text { Fasting } \\
3 \\
5\end{array}$ & $\begin{array}{l}182 \\
180 \\
189\end{array}$ & $\begin{array}{l}7.2 \\
8.6 \\
8.9\end{array}$ & $\begin{array}{l}3.2 \\
2.6 \\
2.9\end{array}$ & $\begin{array}{l}0.96 \\
1.07 \\
1.18\end{array}$ \\
\hline \multirow[t]{2}{*}{$\mathrm{M}_{\mathrm{F}} \mathrm{D}$. } & Control & $\begin{array}{c}\text { Fasting } \\
3 \\
5\end{array}$ & $\begin{array}{l}205 \\
217 \\
214\end{array}$ & $\begin{array}{r}9.7 \\
11.1 \\
10.9\end{array}$ & $\begin{array}{l}1.7 \\
2.8 \\
2.7\end{array}$ & $\begin{array}{l}0.45 \\
0.57 \\
0.57\end{array}$ \\
\hline & $\begin{array}{l}\text { Refeeding on } 4 \text { th day } \\
\text { of starvation }\end{array}$ & $\begin{array}{c}\text { Fasting } \\
3 \\
5\end{array}$ & $\begin{array}{l}252 \\
250 \\
255\end{array}$ & $\begin{array}{l}11.9 \\
13.9 \\
12.9\end{array}$ & $\begin{array}{l}5.6 \\
6.3 \\
6.4\end{array}$ & $\begin{array}{l}2.12 \\
1.25 \\
1.13\end{array}$ \\
\hline
\end{tabular}

${ }^{*} \mathrm{Bk}=$ breakfast containing $60 \mathrm{~g}$ of fat but no carbohydrate.

phosphorus (11) were determined on a chloroformmethanol extract. Triglyceride concentration was estimated by subtracting the fatty acids estimated to be combined with cholesterol and phospholipid from the total fatty acids. Blood glucose (12) was determined in the subjects receiving glucose.

\section{RESULTS}

Response to fat meal. The results are listed in Table I. Three and five hours following the control breakfast, the plasma FFA concentration increased in all six subjects, and triglyceride con- centration increased in five of the six subjects. Plasma cholesterol and phospholipid concentrations did not change consistently.

In three subjects studied during the course of starvation, two of whom are represented in Figures 1 and 2, a rise in plasma FFA during the first day of starvation was indistinguishable from the changes after the fat meal. With continuation of starvation there was a definite but not consistent afternoon rise, with a drop occurring by the next morning. The overall trend was that of a progressive increase in plasma FFA concentration. 
On the final morning of starvation, the FFA had increased in the plasma of all subjects from an initial average concentration of $0.39 \mathrm{mEq}$ per $\mathrm{L}$ on the control morning to an average of 1.89 $\mathrm{mEq}$ per L (Tables I and II, Figures 1 and 2). The highest concentration of $2.7 \mathrm{mEq}$ per $\mathrm{L}$ was achieved in the subject who had fasted a week (R. N.). An increase in cholesterol concentration occurred in the plasma of only three of the subjects, and in the concentration of triglycerides in five. The increases in triglyceride concentration were less than $5 \mathrm{mEq}$ per $\mathrm{L}$, and might in part represent FFA partially included in the chloroform-methanol extract.

The fat meal which terminated the fast produced an opposite effect on plasma FFA concentration from that of the control meal in five of the six subjects : in all but one female subject (J. G.), a sharp drop in concentration of FFA occurred three and five hours after the fat meal (Table I). The subject receiving no protein with his breakfast (B. B.) had as marked a drop as the others.
All uniformly reported restitution of energy and sense of well-being following the refeeding, with disappearance of weakness and fatigue which had become prominent during the starvation period. In one subject the fat breakfast was repeated one week following the termination of starvation (A. M.). The FFA response was intermediate between the control response and the post-starvation response.

Alimentary rise in triglyceride concentration was slightly lower following the starvation period than in the control period of five of the six subjects.

Response to oral glucose. Table II shows the slight fall in all lipid components and a marked fall in FFA when glucose was given after an overnight fast (control). After three days of starvation the high concentrations of FFA achieved by the fasting fell abruptly following the ingestion of glucose, reaching normal concentrations two and three hours after the glucose. Slight decrease in the concentration of all serum lipid frac-

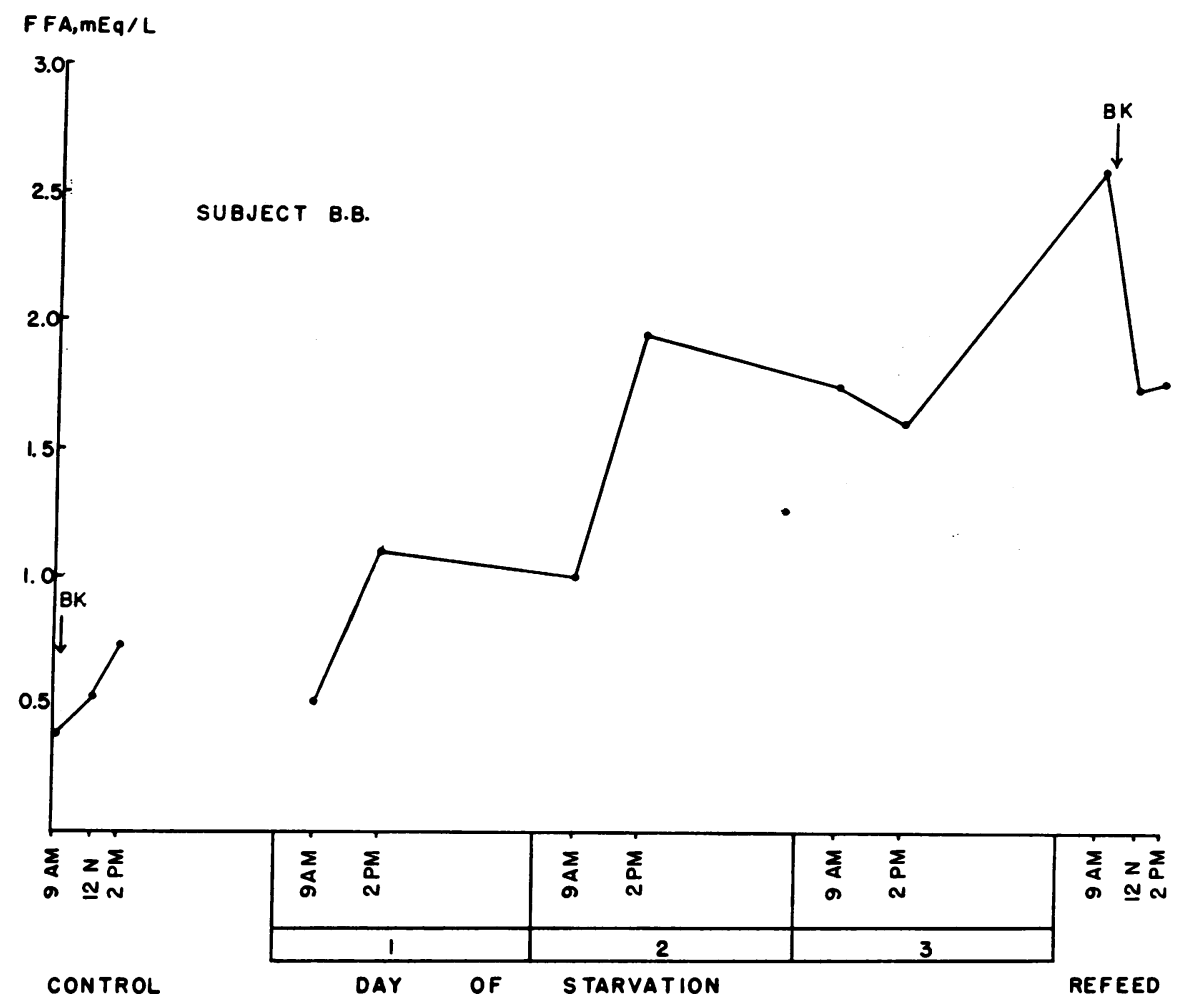

Fig. 1. Subject B. B., Plasma free fatty acids before and after a control fat MEAL, DURING A THREE DAY PERIOD OF STARVATION, AND AFTER FEEDING A FAT MEAL AT THE CONCLUSION OF THE STARVATION PERIOD. FFA = free fatty acids; $B K=$ breakfast containing $60 \mathrm{~g}$ of fat but no carbohydrate. 
FFA, MEq/L

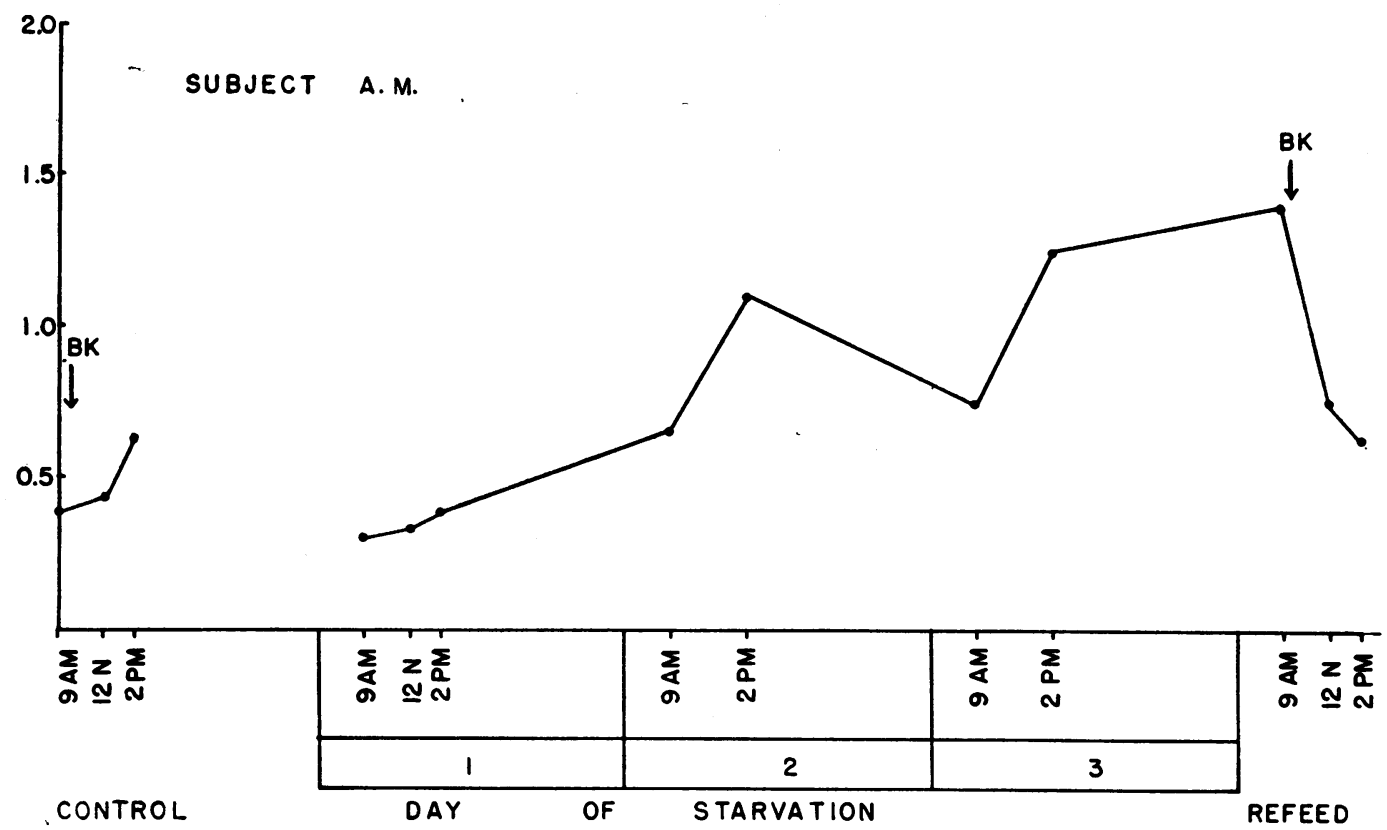

Fig. 2. Subject A. M., PLASMa free fatty ACids before and AFter a control fat Meal, during a THREE DAY PERIOD OF STARVATION, AND AFTER FEEDING A FAT MEAL AT THE CONCLUSION OF tHe STARVATION PERIOD.

tions occurred in response to glucose. In contrast to the normal glucose tolerance curves of the control day, both subjects displayed markedly diabetic types of tolerance curves on the refeeding day. Despite the profound response of FFA to glucose refeeding, the subjects did not experience a sense of well-being such as that reported by the subjects refed with the fat meal.

TABLE II

Changes in plasma lipids and blood sugar following $100 \mathrm{~g}$ oral glucose given after an overnight fast (control), and terminating a period of three days' starvation

\begin{tabular}{|c|c|c|c|c|c|c|c|}
\hline $\begin{array}{c}\text { Subject } \\
\text { Sex }\end{array}$ & & $\begin{array}{c}\text { Time after } \\
\text { glucose }\end{array}$ & Cholesterol & Lip. $P$ & $\begin{array}{l}\text { Triglyceride } \\
\text { fatty acids }\end{array}$ & FFA & Blood sugar \\
\hline \multirow[t]{2}{*}{$\mathrm{W}_{\dot{\mathbf{M}}} \mathbf{P}$} & Control & $\begin{array}{c}\text { hrs } \\
\text { Fasting } \\
1 \\
2 \\
3 \\
5\end{array}$ & $\begin{array}{c}m g / 100 m l \\
161 \\
156 \\
158 \\
150\end{array}$ & $\begin{array}{c}m g / 100 \mathrm{ml} \\
6.7 \\
6.5 \\
6.6 \\
6.1\end{array}$ & $\begin{array}{c}m E q / L \\
1.7 \\
1.9 \\
1.7 \\
1.4\end{array}$ & $\begin{array}{c}m E q / L \\
0.34 \\
0.21 \\
0.18 \\
0.18 \\
0.63\end{array}$ & $\begin{array}{c}m g / 100 m l \\
87 \\
106 \\
83 \\
83 \\
93\end{array}$ \\
\hline & $\begin{array}{c}\text { Refeeding on } \\
\text { 4th day of } \\
\text { starvation }\end{array}$ & $\begin{array}{c}\text { Fasting } \\
1 \\
2 \\
3 \\
5\end{array}$ & $\begin{array}{l}180 \\
165 \\
165 \\
148 \\
169\end{array}$ & $\begin{array}{l}8.0 \\
7.1 \\
7.2 \\
7.2 \\
7.5\end{array}$ & $\begin{array}{l}3.7 \\
2.8 \\
3.2 \\
1.0 \\
1.7\end{array}$ & $\begin{array}{l}0.94 \\
0.59 \\
0.34 \\
0.25 \\
0.64\end{array}$ & $\begin{array}{r}66 \\
155 \\
157 \\
109 \\
59\end{array}$ \\
\hline \multirow[t]{2}{*}{$\mathrm{D}_{\mathbf{M}} \mathbf{H}$. } & Control & $\begin{array}{c}\text { Fasting } \\
1 \\
2 \\
3 \\
5\end{array}$ & $\begin{array}{l}138 \\
129 \\
135 \\
129 \\
132\end{array}$ & $\begin{array}{l}6.6 \\
6.3 \\
6.4 \\
5.5 \\
6.4\end{array}$ & $\begin{array}{l}0.9 \\
1.2 \\
0.5 \\
0.6 \\
1.2\end{array}$ & $\begin{array}{l}0.41 \\
0.17 \\
0.11 \\
0.11 \\
0.70\end{array}$ & $\begin{array}{r}82 \\
121 \\
79 \\
74 \\
62\end{array}$ \\
\hline & $\begin{array}{c}\text { Refeeding on } \\
\text { 4th day of } \\
\text { starvation }\end{array}$ & $\begin{array}{c}\text { Fasting } \\
1 \\
2 \\
3 \\
5\end{array}$ & $\begin{array}{l}177 \\
155 \\
156 \\
154 \\
161\end{array}$ & $\begin{array}{l}7.9 \\
7.1 \\
7.0 \\
6.9 \\
6.8\end{array}$ & $\begin{array}{r}10.7 \\
8.2 \\
7.1 \\
6.9 \\
6.9\end{array}$ & $\begin{array}{l}2.91 \\
1.20 \\
0.49 \\
0.43 \\
0.99\end{array}$ & $\begin{array}{r}52 \\
186 \\
212 \\
216 \\
110\end{array}$ \\
\hline
\end{tabular}




\section{DISCUSSION}

The abrupt fall in concentration of plasma FFA when a two to seven day fast is terminated by feeding a fat meal is compatible with the hypothesis that fat metabolism becomes more efficient during a period of starvation. This drop is in sharp contrast to the lack of response or even rise in FFA concentration when a fat meal follows a fast of only a few hours or overnight. Evidence currently available supports the theory that a rise in plasma FFA concentration represents mobilization of fat from adipose tissue in response to a caloric deficit (3). Conversely, a decrease in FFA concentration signals caloric satisfaction from exogenous sources with concomitant cessation of delivery of FFA to plasma from adipose tissue. Prior to the present study, only maneuvers which either directly or indirectly increase carbohydrate combustion have been found to "cut off" the release of FFA (3). The failure of a fat meal to produce a fall in plasma FFA concentration under normal circumstances may very well mean that fat alone does not, under these circumstances, provide caloric satisfaction. Following the adaptive changes of starvation, a fat meal evidently does provide caloric satisfaction. The failure of one of the two women in the study to make this adaptation might stem from her sex, her tendency to obesity, or from the brevity of her period of starvation (two days). The decreased alimentary lipemia of all but one subject might be another manifestation of increased fat metabolism, although delayed gastric emptying and slow intestinal absorption cannot be ruled out.

The possible mechanisms whereby starvation increases the efficacy of fat as fuel are worthy of some consideration. Since a greater portion of administered fat is oxidized in briefly starved than in carbohydrate-fed animals (13), it stands to reason that after prolonged starvation, administered fat would be even more completely oxidized with a resultant increase in metabolic rate. If the FFA releasing mechanism responds in some way to energy balance rather than to some specific aspect of carbohydrate metabolism, the effect of refeeding a fat meal might cut off the mobilization of FFA from adipose tissue.

As an alternative explanation for the fall in FFA concentration, the feeding of fat might, by stimulating fat combustion, actually increase the removal rate of FFA from plasma without necessarily influencing the release of FFA from adipose tissue. Although changes in FFA concentration are believed to be entirely due to changes in their rate of release from adipose tissue, Bragdon and Gordon (13) have shown that nutritional status affects the removal rate of FFA and chylomicrons differently in different organs. Fat feeding after starvation might, by greatly stimulating fat combustion, have a sufficiently profound effect on the removal rate by some organ or organs to cause an increase in the overall disappearance rate of FFA.

Inherent to both of these possibilities and consistent with the striking sense of well-being reported by subjects refed with the fat meal is the assumption that fat fed after a period of fasting is more completely oxidized than fat fed after only an overnight fast. The adaptive changes occurring in response to starvation are only partially understood. The overall changes of starvation may be summarized as a conservation of carbohydrate and protein, and an increased facility in the combustion of fat (14). The rising concentrations of cholesterol and triglycerides (15) and FFA (4) during starvation reflect the increased transport and metabolism of fat. These changes are associated with enzymatic alterations $(16,17)$, and are probably under hormonal control (18-21). A similar metabolic change occurs in animals adapted to a high fat, low carbohydrate diet, and animals so adapted survive starvation longer and with less ketosis than those adapted to a high carbohydrate diet (22). It would seem reasonable to expect that the converse would also hold true, that a period of starvation would facilitate adaptation to a high fat, low carbohydrate diet. The present study offers evidence that such is the case. Studies of the hormonal changes of one of the subjects in the present paper will be reported separately (21). The beneficial effect of fasting and of carbohydrate restriction on the ketosis and lipemia of diabetics was well known before the insulin era $(23,24)$. A lesser degree of ketosis on the last of repeated episodes of starvation in humans (25) may indicate a similar increased efficiency of fat combustion. An inverse relationship between carbohydrate and fat metabolism is present 
in many physiological and pathological conditions (26).

\section{SUM M ARY}

When six normal subjects who had fasted overnight were fed a meal containing $60 \mathrm{~g}$ of fat but no carbohydrate, the plasma FFA increased slightly but consistently in all subjects within five hours after the meal.

A period of starvation of from two to seven days' duration caused an increase in plasma FFA concentration from an average of 0.38 after an overnight fast to an average of $1.85 \mathrm{mEq}$ per $\mathrm{L}$ at the end of the fast. Variable increases in concentration of serum cholesterol and triglyceride were also noted.

A meal identical in composition to the control meal was given as the first meal terminating the starvation. In contrast to the control meal, this meal was followed by an abrupt decrease in the elevated concentrations of plasma FFA for five of the six subjects.

The present study thus reports a marked fall in FFA when a fat meal follows a period of starvation. This is in contrast to the small alterations in FFA following a fat meal after usual alimentation, and is a manifestation of the adaptive changes occurring during starvation and indicative of increased efficiency of fat metabolism.

\section{REFERENCES}

1. Gordon, R. S., Jr., and Cherkes, A. Unesterified fatty acid in human blood plasma. J. clin. Invest. 1956, 35, 206.

2. Dole, V. P. A relation between non-esterified fatty acids in plasma and the metabolism of glucose. J. clin. Invest. 1956, 35, 150.

3. Fredrickson, D. S., and Gordon, R. S., Jr. Transport of fatty acids. Physiol. Rev. 1958, 38, 585.

4. Laurell, S. Plasma free fatty acids in diabetic acidosis and starvation. Scand. J. clin. Lab. Invest. 1956, 8, 81.

5. Bierman, E. L., Dole, V. P., and Roberts, T. N. An abnormality of nonesterified fatty acid metabolism in diabetes mellitus. Diabetes 1957, 6, 475.

6. Rich, C., Bierman, E. L., and Schwartz, I. L. Plasma nonesterified fatty acids in hyperthyroid states. J. clin. Invest. 1959, 38, 275.

7. Albrink, M. J., Fitzgerald, J. R., and Man, E. B. Reduction of alimentary lipemia by glucose. Metabolism 1958, 7, 162.

8. Piskorski, J. M., and Man, E. B. Serum non-esterified fatty acids in patients with recent myocardial infarctions. Proc. Soc. exp. Biol. (N. Y.) 1959, $100,473$.

9. Albrink, M. J. The microtitration of total fatty acids in small amounts of serum, with notes on the estimation of triglycerides. J. lip. Res. 1959, 1, 53.

10. Abel, L. L., Levy, B. B., Brodie, B. B., and Kendall, F. E. A simplified method for the estimation of total cholesterol in serum and a demonstration of its specificity. J. biol. Chem. 1952, 195, 357.

11. Fiske, C. H., and Subbarow, Y. The colorimetric determination of phosphorus. J. biol. Chem. 1925, 66, 375 .

12. Nelson, N. A photometric adaptation of the Somogyi method for the determination of glucose. J. biol. Chem. 1944, 153, 375.

13. Bragdon, J. H., and Gordon, R. S., Jr. Tissue distribution of $\mathrm{C}^{14}$ after intravenous injection of labeled chylomicrons and unesterified fatty acids in the rat. J. clin. Invest. 1958, 37, 574.

14. Keys, A., Brozek, J., Henschel, A., Mickelsen, O., and Taylor, H. L. The biology of human starvation. Minneapolis, The University of Minnesota Press, 1950, vol. I.

15. Kartin, B. L., Man, E. B., Winkler, A. W., and Peters, J. P. Blood ketones and serum lipids in starvation and water deprivation. J. clin. Invest. 1944, 23, 824.

16. Tepperman, H. M., and Tepperman, J. The hexosemonophosphate shunt and adaptive hyperlipogenesis. Diabetes 1958, 7, 478.

17. Hollenberg, C. H. Effect of nutrition on activity and release of lipase from rat adipose tissue. Amer. J. Physiol. 1959, 197, 667.

18. Russell, Jane A. Effects of growth hormone on protein and carbohydrate metabolism. Amer. J. clin. Nutr. 1957, 5, 404.

19. Raben, M. S., and Hollenberg, C. H. Effect of growth hormone on plasma fatty acids. J. clin. Invest. 1959, 38, 484.

20. White, J. E., and Engel, F. L. Lipolytic action of corticotropin on rat adipose tissue in vitro. J. clin. Invest. 1958, 37, 1556.

21. Neuwirth, R. S., and Bondy, P. K. Unpublished observations.

22. Whitney, J. E., and Roberts, S. Influence of previous diet on hepatic glycogenesis and lipogenesis. Amer. J. Physiol. 1955, 181, 446.

23. Allen, F. M., Stillman, E., and Fitz, R. Total dietary regulation in the treatment of diabetes. Rockefeller Institute for Medical Research, 1919, Monograph No. 11.

24. Blix, G. Studies on diabetic lipemia. II. Acta med Scand. 1926, 64, 175.

25. Taylor, H. L., Brozek, J., Henschel, A., Mickelsen, O., and Keys, A. The effect of successive fasts on the ability of man to withstand fasting during hard work. Amer. J. Physiol. 1945, 143, 148.

26. Man, E. B., and Albrink, M. J. Serum lipids in different phases of carbohydrate metabolism. Yale J. Biol. Med. 1956, 29, 316. 